\title{
Sven Olov Lindholm and the literary inspirations of Swedish fascism
}

\begin{abstract}
Very little research has been done into the leader of the most prominent Swedish fascist party of the interwar period, the leader of the NSAP, Sven Olov Lindholm, in spite of extensive source material in his personal archive. This article explores the literary influences on his politics which Lindholm cited in his private documents and interviews, both contemporary and post-war. The immediate impact of notable Swedish writers, poets especially, such as Verner von Heidenstam, Viktor Rydberg, Esaias Tegnér, and Bertel Gripenberg is demonstrated. These authors, largely of the Swedish Romantic tradition, are shown to be parts of one major Scandinavian cultural current in particular, namely Gothicism [göticism], manifested through a centuries-long interest in the Old Nordic heritage. In Sweden, the influence of new far-right ideas that made their way into the country in the 1920s intersected with Gothicism in unique ways, which put Swedish fascists in a peculiar relationship to both fascism and their national heritage. Ultimately these literary Gothicist influences allowed a particular naturalising codification of Swedish fascism in the 1930s. Under the influence of above all contemporary Finno-Swedish health specialist Are Waerland, Lindholm is shown to have actively shaped Swedish fascism in line with his literary exemplars.
\end{abstract}

Keywords: fascism, gothicism, Sven Olov Lindholm

Little has yet been written about Sven Olov Lindholm (1903-98), the leader of the Swedish

Nationalsocialistiska Arbetarepartiet (NSAP, National Socialist Workers' Party) from 1933 until 195 .

The NSAP placed itself firmly on the Left of fascist ${ }^{1}$ politics, and espoused the establishment of a

'workers' Sweden' (arbetar-Sverige), a folkgemenskap of 'labourers of hand and mind' to be

achieved on the basis of a racially pure people and the exclusion of foreign, especially Jewish,

elements. While Swedish fascism did not manage to make any notable electoral gains, it attracted

a disproportionate amount of public attention through street activism and propaganda. The NSAP

in particular regularly attracted crowds of thousands in the cities, with a significant number of

sympathisers outside the party ranks. ${ }^{2}$ The NSAP was the largest of Sweden's interwar fascist

movements, and while by no means the only one of note, perhaps the most interesting one.

Formed as a break-away movement from Sveriges Nationalsocialistiska Parti (SNSP, Sweden's

\footnotetext{
${ }^{1}$ Throughout this article the terms fascism and National Socialism/Nazism will be used interchangeably. Contemporaries distinguished between the two terms in varying and mutually irreconcilable ways, but not in a way that substantially affects the argument of this article. The term fascism is preferred to highlight the wider academic debate about fascism in Europe in which this article is situated.

${ }^{2}$ Klas Åmark, Att Bo Granne Med Ondskan: Sveriges Förhållande till Nazismen, Nazityskland Och Förintelsen

(Stockholm: Bonniers, 2011), pp. 288-304.
} 
National Socialist Party) 15 January 1933, it set itself apart with its revolutionary ethos. In the following years it established itself as the largest and most active fascist organisation in Sweden, especially after the dissolution of the SNSP in 1936. The NSAP peaked at over 10 ooo members in the mid-3os; it got circa $0.7 \%$ of the vote in the 1936 general elections, but managed to attain more substantial results in city elections, especially in Gothenburg. The NSAP declined after the mid-3os, until in November 1938 an effort was made to diversify the party's appeal and make it more respectable, by changing the name to Svensksocialistisk Samling (SSS, Swedish Socialist Union) and discarding symbols like the swastika. The party newspaper Den Svenske Nationalsocialisten (DSN, the Swedish National Socialist) was rebranded Den Svenske Folksocialisten (DSF, The Swedish People's Socialist). This proved to be to no avail, and the NSAP/SSS remained marginalised in Swedish politics, until it dissolved itself in 1950. Throughout this entire period the party was led by an idealistic young NCO from a Stockholm artillery regiment, who had served in leading roles in other fascist parties since 1925 .

Sven Olov Lindholm stands out as a fascist leader, not just in the Swedish far-right, but amongst European fascist leaders. Where there often seemed to be a considerable gap between the charismatic myth of the leader and the banal reality, Lindholm appeared to embody some of the most cherished fascist ideals. Twenty-nine years old when he founded the NSAP, he conformed physically to the stereotype of the masculine Nordic warrior. Tall, blue-eyed, blonde, and classically handsome, he was used to an outdoors military life, and always engaged in gymnastics and hiking. In party life he won the admiration of his devotees through his active involvement in activism and propaganda, speaking at hundreds of meetings a year, personally distributing party literature, living off a minimal wage which made him famous for his ascetic lifestyle. The rest of his time he often spent in study, reading classic literature and writing articles 
and poetry for the party press. He preached as he practised, and advocated a revolutionary activist and military masculinity, embodying youth and dynamism in harmony with intellectual and cultural development. His example had great importance for mobilising the NSAP/SSS, the character of its fascist street activism, and the cadres it attracted - particularly youths, students, and soldiers.

While Lindholm's lifestyle and leadership would be worth studying in greater depth for this reason alone, he also wrote and spoke extensively about his experiences in the post-war period, leaving a small wealth of material to the archives. Lindholm presents a unique opportunity for historians, as a fascist leader who survived the Second World War by several decades, abandoned his political faith, and engaged critically with his political past. Apart from his private diary, recording his everyday activities for most the 193 os and 4Os, he left memoirs of his time in the military and politics for his daughter. The memoirs, entitled Soldatliv och Politik (Soldier Life and Politics), were written in the 1980s, and sketch out Lindholm's life's story, and were intended to supplement his diaries. He also gave an extensive recorded interview in 1980-81 for the Swedish National Archive [Riksarkivet], with Ingemar Carlsson, in which he gave a prepare account of his life in politics, and thoughts on fascism and Nazism, in response to Carlsson's questions, which provides a great deal of influence on the NSAP/SSS's internal politics. In 1967 he also wrote an apologia about his time in politics, considering the various influences on his ideology throughout his life. Together these documents amount to hundreds of pages of Lindholm's personal recordings. Yet the majority of this material remains unused by historians, though it provides an unusually personalised and in-depth perspective on an interwar fascist leader, and gives direct insight into his politics. 
Needless to say these personal documents need to be used with caution, but there can be no doubt that they are able to shed light on how fascist ideas emerged and developed at a personal level, and were translated into fascist praxis. Most importantly for the present study, Lindholm extensively recorded his reading, both as a youth and in adulthood, allowing us to form an unusually clear view of his literary diet. Throughout his writings he repeatedly emphasised the importance of Swedish literature to his political ideas, to the extent that it could be argued that poetry and literary fiction rivalled or even surpassed overtly political tracts in influencing Lindholm's politics. It is therefore precisely those literary works which will be the focus of this article. In addition to Lindholm's personal files, documents from the NSAP/SSS party archive, including correspondence and propaganda, will be used, as well as the party paper DSN/DSF. These provide the additional evidence that Lindholm's literary preoccupations were reflected in the party at large.

I will be exploring some of the origins of Lindholm's ideas, as it can be retraced in the literature which he read, embodied in his ideal of a youthful, militaristic, but cultured fascist masculinity. This aspect of his character has been too easy to dismiss as 'generically fascist', but since the beginning of this century Swedish historians have argued for further engagement with the peculiarly Swedish roots of fascist or National Socialist ideas in Sweden. The most notable is Lena Berggren's 2002 article, the wonderfully titled 'Swedish Fascism - Why Bother?', which argued against the historiography which posited that fascism was alien to Sweden. ${ }^{3}$ While Swedish fascists were necessarily influenced by foreign examples, fascism had important native roots and inspirations, pointing to figures like the authoritarian political scientist Rudolf Kjellén, indigenous

\footnotetext{
${ }^{3}$ Lena Berggren, 'Swedish Fascism: Why Bother?', Journal of Contemporary History, 37.3 (2002), 395-417; also published in Sweden as: Lena Berggren, 'Den svenska mellankrigsfascismen - ett ointressant marginalfenomen eller ett viktigt forskingsobjekt?', Historisk Tidskrift, 2002, 427-44.
} 
anti-Semitism, ${ }^{4}$ and the advanced state of racial science in Sweden. ${ }^{5}$ Some of these arguments go back to one of the first historians of Swedish fascism, Eric Wärenstam, who argued in 1970 that many of the National Socialist intellectual currents already existed in Sweden, but that it was Hitler's rise to power which gave them new currency. ${ }^{6}$ But the precise relationship in Swedish fascism between indigenous ideas and Nazi 'import' remains obscure. Research has in the past decades focused almost entirely on traditional political ideas and staples of fascist ideology such as corporatism or anti-Semitism, but rarely tied these explicitly to the fascist figures that supposedly drew on them, nor looked much beyond the realm of programmatic ideology. More recent publications, such as Klas Åmark's comprehensive 2011 work on Sweden's wartime relationship with Nazi Germany, Att Bo Granne med Ondskan (To Be Evil's Neighbour), investigates fascism in Sweden with unprecedented detail, and takes full account both of Lööw's and Berggren's research, but has a rather old-fashioned moralising approach to the subject, and does not seek to understand the indigenous fascists in their own right. ${ }^{7}$ Amark's work is also symptomatic of a much stronger academic interest in Nazi Germany's influence on, and activities in, Sweden, rather than indigenous fascism. ${ }^{8}$

One exception is Victor Lundberg, who, in his 2016 essay 'Within the Fascist World of Work', was the first to engage directly with Lindholm's ideas, placing Swedish fascism in a

\footnotetext{
${ }^{4}$ Lena Berggren, Nationell Upplysning: Drag i den svenska antisemitismens idéhistoria (Stockholm: Carlsson Förlag, 1999).

${ }^{5}$ Maria Björkman and Sven Widmalm, 'Selling Eugenics: The Case of Sweden', Notes and Records of the Royal Society of London, 64.4 (2010), 379-400.

${ }^{6}$ Eric Wärenstam, Fascismen Och Nazismen i Sverige 1920-1940: Studier i Den Svenska Nationalsocialismens, Fascismens Och Antisemitismens Organisationer, Ideologier Och Propaganda under Mellankrigsåren (Stockholm: Almqvist \& Wiksell, 1970), p. 15.

${ }^{7}$ Klas Åmark, Att Bo Granne Med Ondskan: Sveriges Förhållande till Nazismen, Nazityskland Och Förintelsen (Stockholm: Bonniers, 2011).

${ }^{8}$ See also recent research on German infiltration of Swedish clubs and corporations, e.g.: Birgitta Almgren, 'SvenskTyska Föreningar: Mål För Nazistisk Infiltration', Historisk Tidskrift, 135.1 (2015), 63-91; Sven Nordlund, '"Tyskarna Själva Gör Ju Ingen Hemlighet Av Detta." Sverige Och Ariseringen Av Tyskägda Företag Och Dotterbolag', Historisk Tidskrift, $125 \cdot 4$ (2005), 609-41.
} 
transnational network and bringing out the international influences. Developing a point first made in his 2014 monograph En Idé Större än Döden (An Idea Greater than Death), ${ }^{9}$ Lundberg suggests Ernst Jünger as the main and fundamental influence on the NSAP leader. ${ }^{10}$ While ostensibly a good fit for the military-proletarian National Socialist leader, who read German and visited Germany several times from 1929 onwards, Lundberg's argument does have a very serious flaw. While there can be no doubt of the great importance of the transnational transfer and exchange of ideas in both European fascism and Swedish fascism specifically, there is no immediate evidence that Lindholm ever actually read Ernst Jünger. Lundberg admits that 'how these ideas were transmitted between Jünger and Lindholm is not clear', and suggests that 'Jünger's ideas may have reached Lindholm through the circles around Rohm [sic] and Strasser, which Lindholm had personal connections to before the liquidations in July 1934 '. ${ }^{1}$

While this is a reasonable suggestion, it is severely undermined by the archival material. As noted above, he had a habit of recording his reading. From his memoirs and interview we know what he read in his youth, and his diary records his reading in the 1930s. Whatever reading inspired Lindholm was often evident from his articles and similar publications in the party press. None of this material ever mentions Ernst Jünger even once, which seems odd if was indeed the 'main and fundamental ideological inspiration'. While Lindholm certainly did take inspiration from German sources, I suggest that the transnational dynamic that forged fascism in Sweden is rather more complicated than one-sided inspiration from a German origin, which looks rather like a peculiarly old-fashioned argument of 'alien ideology' in a fashionable transnational jacket.

\footnotetext{
${ }^{9}$ Victor Lundberg, En idé större än döden: en fascistisk arbetarrörelse i Sverige, 1933-1945 (Stockholm: Gidlunds Förlag, 2014), p. 110.

${ }^{10}$ Victor Lundberg, 'Within the Fascist World of Work: Sven Olov Lindholm, Ernst Jünger and the Pursuit of Proletarian Fascism in Sweden, 1933-1945', in New Political Ideas in the Aftermath of the Great War, ed. by Salvador Alessandro and Anders G. Kjøstvedt (New York: Palgrave Macmillan, 2016), pp. 199-217 (pp. 209-12).

${ }^{11}$ Lundberg, 'Within the Fascist World of Work', p. 212.
} 
Instead of intellectual influence in a supposed similarity of ideas, I aim to show - with the material from Lindholm's archive and the referenced literary sources - that we need not look so far from home to find the inspiration for Swedish fascist politics. We only need to follow the obvious leads, and look beyond the overtly political literature.

Sven Olov Lindholm's memoirs - 'some small stories from my life, which I have written for my own pleasure in "my old age"' - closes the preface with the first stanza from Verner von Heidenstam's (1859-1940) poem 'Vi Otacksamma' (We, the Ungrateful Ones), regretting how youth does not appreciate the moment. What follows is a brief description of Lindholm's childhood. His parents, Sigrid and Knut Axel, married in 1900; Lindholm was born in 1903 in Jönköping, with one sister and three younger brothers. 1904 the family moved to Hagaberg in Mjölby, Östergötland (East Gothland) where they moved into a villa on the edge of the forest. Knut Axel previously worked in the book trade, but now took over his father-in-law's grain business. The Lindholm family's 'financial status was initially quite good. But we lived a simple life, no luxury." ${ }^{12}$

With evident pride Lindholm wrote of how the plains of Östergötland were fertile and replete with fornminnen (relics of the past). Close to home was the famous Högby rune stone [Ög 81], and the site of Nils Dacke's defeat by Gustav Vasa in $1543 \cdot{ }^{13}$ Sometimes Lindholm would go on excursions to various sites of note with other Mjölby families, and sing patriotic songs such as Sten Granlund's (1871-1917) Östgötasång. 'Yes - we were raised to love our homeland [hembygdskärlek],

\footnotetext{
${ }^{12}$ Sven Olov Lindholm, Soldatliv och Politik, vol. I, p. 1, photocopy in National Archives of Sweden (Riksarkivet), Marieberg, SO Lindholm's archive: 3 A.

${ }^{13}$ Olle Larsson and Andreas Marklund, Svensk Historia (Lund: Historiska Media, 2012), pp. 44-49.
} 
which of course also became patriotism [fosterlandskärlek] - but the foundation for that was mostly nature. "I long for the soil, I long for the stones"'. ${ }^{14}$

Knut Axel was a conservative nationalist, with all the contemporary class associations of Swedish nationalism, to Lindholm's retrospective dismay. Swedish nationalism was represented above all by the conservative Right party [Högern] in this period, and represented property and class boundaries as much as the nation. During the First World War Lindholm listened in on the political discussions of his father's friends. The influence was evident: with some embarrassment Lindholm mentions trying to sabotage the socialist meetings organised by his history teacher, trying to persuade people not to enter the venue..$^{15}$

During the 1980-81 interview at the National Archives Lindholm deemed his childhood and youth 'very decisive' for his later political development. ${ }^{16}$ During the summers of 1916-17, the experience of seeing wounded and maimed soldiers from Russia, Germany, and Austria at the railway station - (prisoners of war being exchanged via Sweden) - left a profound and lasting impression on the teenage Lindholm. The PoW trains made stops for food at Mjölby, and Lindholm would play truant so he could listen to the soldiers' war. Teachers would turn a blind eye to this behaviour, imagining it educational and a good opportunity to practise German. For several summers Austrian war refugees stayed in Mjölby, and Lindholm was regaled with tales from Central Europe. ${ }^{17}$ With one of these boys he became lifelong friends, and in 1980 he still

\footnotetext{
${ }^{14}$ Underscored in the original text. Lindholm, Soldatliv och Politik, I, p. 1.

${ }^{15}$ Ibid., pp. 2-3.

${ }^{16}$ Lindholm interview, by Ingemar Carlsson, 198o-81, tape oo262:B, c. 17.30 mins, Marieberg, SO Lindholm's archive, vol. 4.

${ }^{17}$ For the state of deprivation and hunger in post-war Austria, see: Robert Gerwarth, The Vanquished: Why the First World War Failed to End, 1917-1923 (London: Penguin, 2017), pp. 204-5.
} 
maintained correspondence with him. ${ }^{18}$ After finishing school at the age of sixteen, Lindholm joined the army, and became an NCO in the artillery.

But more important than anything else were books:

The central influence for my attitude to life was the extensive literature at home. These were mostly works of literary fiction [skönliterrära verk] and history - Runeberg, Topelius, Heidenstam, Viktor Rydberg, Cederborg but also Strindberg and many, many [sic]. Very early on I became interested in Swedish history, and consequently politics, which after all was - and is - the history of today. ${ }^{19}$

He made the same point in his 1943 book, Svensk Frihetskamp ('Swedish Freedom Struggle'): 'of course we derived much from literature, consciously or subconsciously'. ${ }^{20}$ In the $1980-81$ interview Lindholm again mentioned literary influences as being crucial, listing the same authors, but also including the Nobel Prize-winning Selma Lagerlöf, and the historian Carl Georg Starbäck. ${ }^{21}$ Reading remained a favourite pastime in the 1920s and 1930s, especially poetry and classical novels [kulturromaner] during what he termed his 'political age'. In the 193os Lindholm read more overtly political texts, both Italian and German ideologists. He mentioned Walther Darré, and Alfred Rosenberg's Der Mythus des zwanzigsten Jahrhunderts (1930, 'The Mythos of the Twentieth Century') (a tedious and difficult, but apparently necessary book), but made no mention of Ernst

\footnotetext{
${ }^{18}$ Lindholm interview, 00262:B., c. 21.00 mins.

${ }^{19}$ Lindholm, Soldatliv och Politik, I, p. 4.

${ }^{20}$ Sven Olov Lindholm, Svensk Frihetskamp (Stockholm, 1943), p. 19.

${ }^{21}$ Lindholm interview, 00262:B, c. 28.30 mins.
} 
Jünger. Lindholm made a point of stating that he had never read Hitler's Mein Kampf, except for extracts. $^{22}$

Two of Lindholm's favourite contemporaneous writers, the aforementioned Verner von Heidenstam and Selma Lagerlöf (1858-1940), played a prominent role in the Swedish fin de siècle movement for regenerating a sense of Swedishness [svenskhet $]{ }^{23}$ None of Lagerlöfs books were more renowned than the 1906-o7 Nils Holgerssons Underbara Resa genom Sverige ('Nils Holgersson's Wonderful Journey through Sweden'), about the Småland boy Nils, who, magically shrunken, makes a geographically educational journey through the country on the back of a goose. Lagerlöf's book had widespread and lasting appeal, but was not without racist, and particularly anti-Semitic and anti-Ziganist, undertones, although she vehemently rejected German Nazi overtures in the 1930s. ${ }^{24}$ Lindhom especially enjoyed Heidenstam's poetry cycle 'Ett folk' (1899, 'One People'). Heidenstam argued for universal suffrage and social equality, and condemned the evils of commerce while referring back to Sweden's patriotic history in 'Medborgarsången' ('Citizens' song'):

As truly as we own a fatherland, we all inherited it equally, with the same right and the same tie for both poor and rich; and therefore we wish to vote freely as once among shields and bows,

\footnotetext{
${ }^{22}$ Ibid., c. 30.00 mins.

${ }^{23}$ Interestingly, both Lagerlöf and von Heidenstam were among the founders of the Swedish-German Union, a key organisation for infiltration by the Nazi government in the 193os. Birgitta Almgren, 'Svensk-Tyska Föreningar: Mål För Nazistisk Infiltration', Historisk Tidskrift, 135.1 (2015), 63-91 (p. 70).

${ }^{24}$ Larsson and Marklund, pp. 316-18.
} 
and not to be weighted amidst merchants,

like money bags on scales.

We fought together for home and hearth,

when our coasts were burnt.

It was not the lords alone who grasped the sword,

when the warning beacons were lit.

It was not the lord alone who went down,

but also the lords' labourers.

It is shame, it is a stain on Sweden's standard,

that citizen's right is money.

Heidenstam's poetry had immediate appeal to a young nationalist soldier, with a keen sense of the social inequalities that marked the Swedish nation and army. The association of citizenship with the military, and of the lower classes with military defence, expressed a crucial idea that would recur in Lindholm's ideology, what he termed soldier socialism (soldatsocialismen) in Svensk Frihetskamp. ${ }^{25}$ (In 1939 the party newspaper, in celebration of Heidenstam's eightieth birthday, published an article in praise of his nationalism. Lindholm sent Heidenstam a congratulatory telegram on behalf of the $\mathrm{SSS}^{26}$ )

The military theme was also prominent in the work of Finno-Swedish poets whom Lindholm enjoyed. One such was Johan Runeberg (1804-1877), commonly regarded as the national poet of Finland, famous for writing the national anthem and the epic poem Vänrikki Stoolin

\footnotetext{
${ }^{25}$ Lindholm, pp. $16-18$.

${ }^{26}$ 'Heidenstams nationalism: Några tankar vid skaldens 8o-årsdag i morgon', Den Svenske Folksocialisten [DSF], no 46, 5 July 1939, pp. 1-2, 4; for the telegram, see: 'SSS hyllade Heidenstam', DSF, no 48, 12 July 1939, p. 1.
} 
Tarinat (1848-6o, Fänrik Ståls Sägner, 'The Tales of Ensign Stål') ${ }^{27}$ According to Lindholm, the SSS volunteers in the Soviet-Finnish Winter War of 1939-40 had 'quite a lot of Runebergesque national romanticism in their spiritual baggage, which helped them through many difficulties. And our foremost (and first) volunteer, Gösta Hallberg-Cuula ... was as if straight out of Fänrik Ståls Sägner, ${ }^{28}$ Another poet was Bertel Gripenberg (1878-1946), a nationalist who fought in the White Army in the 1918 Finnish Civil War, and later became a member of the Lapua movement. His 1918 collection Under Fanan ('Under the Flag') glorified the struggle against Bolshevism in a series of romantic military poems:

\author{
Beautiful is the soldier when he stands \\ in peril calm and cold, \\ beautiful is his manly deed \\ and beautiful at last his fall. \\ You nation that ennobled the battle, \\ you nation that awoke peril, \\ over you is the spirit of the fathers, \\ over you is the air of the deed. ${ }^{29}$
}

Gripenberg's poetry was printed in the NSAP party newspaper DSN, and Lindholm closed the first party congress of the NSAP in 1933 with his poem 'Invokation':

\footnotetext{
${ }^{27}$ Lindholm quotes Runeberg's poetry among other places in: Soldatliv och Politik, I, p. 28.

${ }^{28}$ Letter [copy], Lindholm to Lennart Westberg, Rönninge, 24 October 1977, p. 6, Marieberg, SO Lindholm's archive, vol. 5 .

${ }^{29}$ Bertel Gripenberg, Under Fanan (Helsingfors: Holger Schildts Förlag, 1918), p. 41.
} 
Short is my time, merely a single drop in the world ocean I am,

already decayed, the autumnal gold vestment of decline I wear!

Life is eternal and dark and cruel and icy cold -

nothing I am, but my race and my root and my tribe is all! ${ }^{30}$

In his 1967 apologia Döm ingen ohörd ('Judge none without a hearing'), he described this as a fusion of nationalism and socialism indigenous to Sweden, and the NSAP/SSS as the party political expression of various Swedish poets and political thinkers. Texts such as 'Medborgarsången' are mentioned explicitly. ${ }^{31}$ During his interview in the eighties, Lindholm recalls his time as an NCO during the war, reciting Runeberg's poem 'Torpflickan' (The Village Girl) for the troops in the morning, who responded favourably. 'After all it deals with a theme of contemporary relevance, about how one's own demand for welfare, yes, even love, must be sacrificed for the greater duty towards land and nation [land och folk]. ${ }^{32}$ Of course Lindholm's retrospect of his political past needs to be treated with caution, and reflects a particular interest to defend his reputation as a misguided but fundamentally benevolent patriot. It can also be seen as part of a consistent, decades-long attempt since 1938 to distance the NSAP from Nazi Germany; ${ }^{33}$ Lindholm was a keen admirer of Nazi Germany since the late 1920 s when he visited the Nuremberg Parteitäge, and it is only in the mid-to late thirties that he adopted a more critical perspective, especially after the Night of the Long Knives in June 1934, which he retrospectively

\footnotetext{
${ }^{30}$ For the text, see: Bertel Gripenberg, 'Invokation', $D S N$, no 2, 9 January 1935, p. 4. For the report on Lindholm's recital, see: 'Göteborg i N.S.A.P:s tecken', DSN, no 13, 11 June 1933, p. 3.

${ }^{31}$ Sven Olov Lindholm, Döm ingen ohörd, 2nd edition, (1969), p. 10, Marieberg, SO Lindholm's archive, vol. 8.

${ }^{32}$ Lindholm interview, oo26o:B, c. 1 min.

${ }^{33}$ Nathaniël Kunkeler, 'The Evolution of Swedish Fascism: Self-Identification and Ideology in Interwar Sweden',

Patterns of Prejudice, 50.4-5 (2016), 378-97.
} 
deemed the end of authentic National Socialism. ${ }^{34}$ One year after the Second World War,

Lindholm complained, de-emphasising SSS connections to the Nazi regime, that ' $[\mathrm{t}]$ he general

impression of our movement has been skewed so badly by the newspaper press, that one could say our aims are approximately the opposite of what the general public believes. ${ }^{35}$ In the 1980 os

Lindholm was still corresponding with journalists and historians, complaining of how he was

portrayed in contemporary media, perhaps subconsciously attempting to salvage the reputation of the NSAP/SSS. ${ }^{36}$ Regardless, there is no serious reason to doubt Heidenstam, Gripenberg and others had influence on Lindholm's political development in the 1910s and 2os. They were a lifelong inspiration to him personally, and this evidently trickled down to the cadres through party literature. If these contemporary nationalist literary influences can explain something of Lindholm's ideology, we must also consider the more widely established literary-cultural conditions that allowed these ideas to flourish.

\section{II}

Lindholm's literary diet is notable for its high proportion of poetry, history, and Swedish nineteenth-century Romantic works, which were reflective of his school reading. Typically enough, Lindholm mentioned King Charles XII (1682-1718) as a major inspiration in his life, 'since I was heavily influenced by the national romanticism [nationalromantik] which already took root in my

\footnotetext{
${ }^{34}$ Lindholm, Soldatliv och Politik, I, p. 101.

${ }^{35}$ Letter, Lindholm to editors of Svenska Män och Kvinnor (Albert Bonniers), Stockholm, 22 June 1946, Lindholm's archive, vol. 5 .

${ }^{36}$ E.g.. Letter, Lindholm to Heléne Lööw, Rönninge, 12 September 1987, Lindholm's archive, vol. 5 .
} 
school education' ${ }^{37}$ In nineteenth-century literature Charles XII, and other kings like Gustav II Adolf (1594-1632), and Gustav Vasa (1496-156o), as well as folk heroes like Nils Dacke, were portrayed in an idealistic fashion. Since national elementary school education [folkskolan] was introduced in 1842, inspired by the Danish example of folkundervisning in 1814, patriotic revivalism had been a cornerstone of Swedish education. Traumatised by the loss of Finland to Russia in 1809, and later the 1905 secession of Norway from Sweden, national education was directed towards the strengthening of the Swedish 'national character'. One of the chief pedagogic tools in this mission was emphasis on the heroic elements of Swedish history, and the Swedes' noble racial roots..$^{38}$

No Swedish curriculum was complete without two of the Romantic era's most beloved and enduring poets, both of which featured more prominently in Lindholm's mind than perhaps any others: Esaias Tegnér and Viktor Rydberg. Tegnér (1782-1846) ranks among Sweden's foremost modern and Romantic poets, while Rydberg (1828-1895) has been described as Sweden's last Romantic author. In difficult times Lindholm consoled himself with Tegnér's poetry, and used it to inspire the party cadres, especially the poem 'Svea' (written 1809, published 1814), which he learnt by heart at an early age. 'Svea' was a call to arms to re-conquer Finland 'within Sweden's borders', to save the fatherland from decadence, opening with the lines:

Earth, which has raised me and hides the ashes of our fathers, people [folk], which has inherited a heroes' land and forgets their virtues, from the shadow of my valley I dedicate to you a song. You are put to sleep by the voice of flattery, hear the voice of truth but once.

\footnotetext{
${ }^{37}$ Lindholm interview, 00262:B, c. 41.00 mins. Cf. the concluding argument of: Nathaniël Kunkeler, 'Narratives of Decline in the Dutch National Socialist Movement, 1931-1945', The Historical Journal, 2017, 1-21 (pp. 20-21) $<$ https://doi.org/10.1017/Soo18246X17000188>.

${ }^{38}$ Larsson and Marklund, pp. 269-72.
} 
Another [voice] sings to you freely of our times' honour

of our new lights and our mild customs.

In the embrace of sumptuous rest he may freely despise

the heroic days gone by, the power which he terms uncouth. [...]

Each has his own disposition. I do not love you, time,

which smiles on us in false and effeminate peace. ${ }^{39}$

Lindholm used it in one crucial DSN article, published in 1938 to justify the party makeover (nyorienteringen, the new direction) which discarded much of the fascist imagery in favour of a more respectably patriotic image. Lindholm concluded his article with a call for a final battle, quoting from the poem's dark imagery to warn of what would happen if the rank-and-file did not give the National Socialist struggle their utmost. ${ }^{40}$ In the summer of 1939, at the SSS party congress for the North of Sweden (Norrland), Lindholm recited the fourteen pages long poem in its entirety, after describing it as programmatic for Swedish National Socialism:

Party leader Lindholm then recollected our great poet Esaias Tegnér, who can rightly be said to be one of the first pioneers for those ideas, for which Swedish-Socialism [read National Socialism] fights today. In his poem Svea, Tegnér has not just portrayed contemporary national problems. The flogging which he justly gives his own time's effeminised generation, and the picture he provides of this generation's state of humiliation is true to an even greater degree now, 130 years later. ${ }^{41}$

\footnotetext{
39 'Svea', in: Esaias Tegnér, Fritjofs Saga, och andra större dikter (Stockholm: Saxon \& Lindströms Förlag, 1935), p. 257.

${ }^{40}$ Sven Olov Lindholm, 'Vår anfallsväg: II. Den politiska utvecklingen', DSN, no 87, 19 November 1938, p. 8.

${ }^{41}$ 'Norrlandsting i regn', DSF, no 44, 28 June 1939, p. 4.
} 
It is probably no coincidence that the SSS elite group, Sveaborg, founded in 1941 and composed initially of volunteers from the Finnish Winter War, was named after the Finno-Swedish fortress which featured prominently in Tegnér's poem: 'Oh stronghold, built by Ehrnsvärd, / recently torn like a bloody shield from the heart of the state'..$^{42}$

Viktor Rydberg occupied a similarly elevated position in Lindholm's nationalist-poetic repertoire. During his 1980-81 interview he was still ready to recite his favourite Rydberg poems by heart. ${ }^{43}$ DSN already printed some of Rydberg's verse in its second ever issue, 2 February 1933, with extracts from 'Snöfrid' ('Snow Peace'), rousing the new party to action in a difficult time of consolidation:

For the hard

runes of a hero's life state:

To the sword against sordid

giants draw,

bleeding bravely

for the weak,

happily forsake, never to complain,

to fight a hopeless battle

and die without a name.

That is life's true heroes' tale!

Do not search for the isle of happiness! ${ }^{44}$

\footnotetext{
${ }^{42}$ Tegnér, 'Svea', p. 262.

${ }^{43}$ Lindholm interview, 00262:B, c. 39.00 mins.

${ }^{44} D S N$, no 2, 2 February 1933, p. 4.
} 
As with Tegnér, Lindholm took opportunities to educate the rank-and-file about one of Sweden's most famous poets, for instance at a Christmas meeting in Stockholm's Auditorium building, after a viewing of Leni Riefenstahl's Der Triumph des Willens. ${ }^{45}$ Lindholm's diary hints that he enjoyed spending time around monuments dedicated to Rydberg. ${ }^{46}$ In Rydberg's case, it was his 'Den nye Grottesången' ('The New Song of Grotte'), a retelling of the Old Norse Grottasöngr, which had captured Lindholm's imagination, and appealed to his socialism. ${ }^{47}$ In the original Edda, two giantesses are forced to grind a magic mill stone, Grotte, for King Frode, which grinds out wealth and happiness, but the two take revenge by singing a prophetic song of vengeance, covertly using it to bring forth an army, and breaking the mill stone. ${ }^{48}$ Rydberg's version is introduced with an anti-Semitic framing story, recounted by the Wandering Jew Ahasverus. The giants are replaced by a proletariat, and Frode is counselled by the Chancellor-Priest to use the mill stone to build a temple for Mammon. The enslaved masses forced to grind the stone are worked ever harder:

With the least waste of power make gold from muscle energy!

That was the question. Here its solution in practice and in theory.

To keep Grotte going through the day and through the night requires, in one estimate,

\footnotetext{
${ }^{45}$ Lindholm diary, 12 December 1937.

${ }^{46}$ Lindholm diary, 11 July 1938.

${ }^{47}$ Like Heidenstam's 'Medborgarsången', he cites it as the literary expression of Swedish fascist ideas, in: Lindholm, Döm ingen ohörd, p. 10.

${ }^{48}$ Viktor Rydberg, Fädernas Gudasaga, m.m., Skrifter av Viktor Rydberg, XII (Stockholm: Albert Bonnier, 1918), pp. 1922.
} 
ten thousand lives per day.

Every second, its wheels are dancing,

profits gold for Frode's throne

and gives temple gold and plansar

for his expensive religion.

$[\ldots]$

If you are driven into Grotte's path,

you are churned out as corpse.

There is no cruelty in this,

merely arithmetic..$^{49}$

More than examples of Swedish nationalist Romanticism, Tegnér and Rydberg were proponents of what was a long-established cultural current: Gothicism (göticismen, also Gothism). Since the early modern period much had been made of the supposed origins of the gothic tribes of ancient Europe in Scandinavia. They were believed to be related to the Gaunts (götar) of West Sweden, whence they spread to the mainland, exercising a decisive influence on Germanic, and indeed European culture. Since the Fifteenth Century Swedes had thus been identified with the Goths, the conquerors of Rome, laying the foundation for Swedish nationalism for centuries to come. Johannes Magnus demonstrated in his 1554 Gothorum Sveanumque historia that Sweden was one

\footnotetext{
49 'Den Nye Grottesången', IV, in: Viktor Rydberg, Dikter (Stockholm: Albert Bonnier, 1929), pp. 224-25.
} 
of the most ancient kingdoms in the world, and in fact the vagina nationum, which was a major inspiration for the Swedish monarchy thereafter. ${ }^{50}$

At the most extreme end of Gothicism were figures like Olof Rudbeck (1630-1702), who emerged during Sweden's time as a self-conscious imperial great power. ${ }^{51}$ While famed for his contributions to the science of human anatomy, he was also a linguist, and produced in 1675 the enormous Atlantica sive Manheim or Atland eller Manheim (Atlantis or Manheim,), a book which set out to prove that Sweden was, in fact, Atlantis. Printed in Swedish and Latin side-by-side, Rudbeck tried to show through a variety of archaeological and linguistic arguments, across some 3000 pages and with a rather imaginative atlas, that ancient Hellenic culture in particular was derived from Nordic culture. ${ }^{52}$ Sweden, Rudbeck confidently stated, had never been under foreign rule, and did not need foreign cultures - it was an insula deorum of powerful, healthy people, a race founded by Japheth after the Flood, made strong by the fierce climate of the North..$^{53}$ Rudbeck's magnum opus was discredited in subsequent decades, when Gothicist fervour cooled down somewhat as Sweden's Baltic empire crumbled, but the notion of the Nordic realm as Manhem, the origin of European culture, had an influential after-life in the far-right. It proved consonant with theories of Aryanism in the Nineteenth Century, which imagined the Aryans as the creative race, which from its origins in Asia founded civilisations along the way until it settled in Northern Europe.$^{54}$ In the 193 os such ideas were echoed in the conspiratorial Manhem Society [Samfundet Manhem], founded by Carl-Enfrid Carlberg (who also funded Lindholm's SSS in the

\footnotetext{
${ }^{50}$ Ernst Ekman, 'Gothic Patriotism and Olof Rudbeck', Journal of Modern History, 34.1 (1962), 52-63 (pp. 52-55).

${ }^{51}$ Introduction to: Sweden's Age of Greatness, 1632-1718, ed. by Michael Roberts (London: Macmillan, 1973), pp. 1-2.

${ }^{52}$ Ekman, p. 59 .

${ }^{53}$ Olof Rudbeck, Atland eller Manheim/Atlantica sive Manheim, 3 vols, I, (Uppsala: 1675), pp. 24-25, 85-87.

${ }^{54}$ Arthur Herman, The Idea of Decline in Western History (London: The Free Press, 1997), pp. 56-59.
} 
late 1930s), which brought together several far-right and pro-German groups, and conspired to overthrow the government during the Second World War..$^{55}$

The more moderate end of Gothicism experienced a huge revival in Scandinavia during the Nineteenth Century, influenced by Romantic trends in Europe, with a revivified interest in all things Old Nordic. Archaeological finds, the digging up of rune stones and the study of runic script, the Icelandic Edda, Old Nordic languages, and the medieval history of the Vikings, underpinned popular Gothicism which had a lasting impact on modern Swedish culture. As Henrik Sandblad observed in his study of Swedish gymnastic and sports culture, Gothicism had a huge impact in shaping the Swedish school curriculum and its orientation towards purportedly Old Nordic virtues, predominantly gymnastics and poetry.$^{56}$ For instance Pehr Henrik Ling (1776-1839), the great-great grandson of Olof Rudbeck, established a gymnastic institute in Stockholm in 1813 with state support, and sought the resurrection of Old Nordic [fornnordisk] masculinity through physical exercise and poetry. His brand of gymnastics spread throughout the country, including the folkskolor. ${ }^{57}$

This era in Swedish culture was bookended by its two most influential poets, Tegnér and Rydberg. Tegnér himself was a member of Götiska Förbundet (Gauntic Society), which aimed to 'revive the old Gaunts' spirit of liberty, masculine bravery, and rational sense..$^{58}$ In 1825 he published Fritjofs saga ('The Tale of Fritjof'), a retelling of the Icelandic saga of King Fritjof, with the goal to 'provide a poetic portrait of the old Nordic heroic life' in epic verse. ${ }^{59}$ Tegnér became

\footnotetext{
${ }^{55}$ Not, it may be added, that it had much hope for success would it have tried - the secret police was entirely aware of their plans. Karl N. Alvar Nilsson, Svensk Överklassnazism, 1930-1945 (Stockholm: Carlsson, 1996), p. 154.

${ }^{56}$ Henrik Sandblad, Olympia och Valhalla: Idéhistoriska aspekter av den moderna idrottsrörelsens framväxt (Stockholm: Almqvist \& Wiksell, 1985), pp. 28-35.

${ }^{57}$ Sandblad, pp. 43-47; Yvonne Hirdman, Urban Lundberg, and Jenny Björkman, Sveriges Historia, 1920-1965

(Stockholm: Norstedts, 2012), p. 106.

${ }^{5}$ Bernhard Risberg, introduction to: Tegnér, p. 7 .

${ }^{59}$ Risberg, p. 17.
} 
wildly popular in subsequent decades, and played an important role in the popular Gothicist revival: in Växjö streets were named after characters from Fritjofs Saga, while popular naming practises looked back to Old Nordic literature for generations to come. Only Viktor Rydberg could rival his popularity in the second half of the Nineteenth Century. ${ }^{60}$ Rydberg's main contribution to Swedish Gothicism was Fädernas Gudasaga (1887, 'The Ancestors' Tale of the Gods'), which 'herewith for the first time places our race's [folkstam] myths ... in the hands of the Swedish youth' ${ }^{61}$ Rydberg, who had done extensive research into Old Nordic religion, published his findings as Undersökningar igermansk mythologi (published in English as Teutonic Mythology) 1886-89, while Fädernas Gudasaga made his research accessible to a wider, younger audience.

\section{III}

Considering Gothicism as a popular cultural phenomenon in Sweden, and Lindholm's personal interest in Gothicist literature, the Nordic race ideology in NSAP discourse appears in a slightly different light. Early writings such as Lindholm's melodramatically titled article 'The race before the hour of destiny: The Nordic spirit threatened with death and destruction', remain heavily reminiscent of the crude race mysticism familiar to scholars of Nazi Germany. ${ }^{62}$ It can hardly be denied that Lindholm's description of the Nordic race as tall, blond, and blue-eyed, and Sweden as 'the most racially pure country in the world' echoes Nazi racialism at its crudest. However, at the same time the discourse of Nordic-Aryan racism had a distinctive resonance with the Gothicism of

\footnotetext{
${ }^{60}$ Sandblad, pp. 261-68.

${ }^{61}$ Preface to: Rydberg, Fädernas Gudasaga, p. 5 .

${ }^{62}$ For a closer analysis of Nazism's race mysticism as opposed to race science, see: Dan Stone, 'Race Science, Race Mysticism, and the Racial State', in Beyond the Racial State: Rethinking Nazi Germany, ed. by Devin O. Pendas, Mark Roseman, and Richard F. Wetzell (Cambridge: Cambridge University Press, 2017).
} 
the previous century, and the literature from Lindholm's school days. 'Almost all Nordic people also have Nordic spiritual qualities, which are expressed in their behaviour and which has left its mark on their history. The most prominent of these qualities are: the will to action [handlingskraften], which urges them to start expansive missions - all the way from the Viking voyages through the many battles and wars to the bold journeys of discovery and the great projects for peaceful progress. ${ }^{63}$ DSN's lamentation about the decline of western culture, 'Our cultural heritage endangered!', similarly rehashed clichéd ideas: 'Our Swedish cultural heritage, for centuries Nordic in character, is now threatened by the cultural-Bolshevik plague [kulturbolsjevikiska pesten]', a threat that could only be countered by National Socialism. ${ }^{64}$ But again, racially defined cultural heritage, embodied by raiding Goths and Vikings, was historically rooted in Swedish nationalist discourse, and a key part of the school education of the fascists of the NSAP.

For the heroic will to action and self-sacrifice, inherent in the Nordic racial soul, Swedish fascists need not look further than their poets. As in Gripenberg's 1905 poem, 'Germaniskt blod: Till dem som hata Finlands svenska finnar' ('Germanic blood: To those who hate Finland's Swedish Finns'): 'Every drop of Germanic blood, / which flows here in the people's throbbing veins, / gives it iron for deeds and exploits, / the courage to endure, the will to wound' ${ }^{65}$ Or the example of one of Lindholm's favourite Rydberg poems, 'Vaknen!' ('Awake!'): ${ }^{66}$

Awake, all hearts of the North,

\footnotetext{
${ }^{63}$ Sven Olov Lindholm, 'Rasen inför ödestimman: Den nordiska andan hotas med död och förintelse', DSN, no 4, 1 March 1933, p. 1.

${ }^{64}$ 'Vårt kulturav i fara! Förfallet triumferar', DSN, no 7, 11 April 1933, p. 3.

${ }_{55}^{6}$ 'Germaniskt blod', from 'Gallergrinden', in: Bertel Gripenberg, Dikter i Urval (Stockholm: Björck \& Börjesson, 1919), p. 103.

${ }^{66}$ Lindholm interview, 00262:b, c. 39.00 mins.
} 
from the long winter sleep!

Listen once more to the voices,

speaking of noble deeds!

You who struggled hard with death,

the flag of the morning light is waving,

rise and follow its destiny!

$[\ldots]$

Awake and behold clearly,

how the fathers here in the North,

strove for more than honour

and for more than glory on earth,

yes, even more than the joy of Valhalla

and a room in the father's house -

to die at the side of the gods

in the final battle for the light! $!^{67}$

Such examples are worth bearing in mind, when considering the cadres' own poems which they sent to the party newspaper in large quantities. (The editors of DSN had to remind readers they had to sometimes wait before they were published, as they were regularly 'flooded with poems'.) ${ }^{68}$ Even as mimetic a fascist slogan as 'Sweden awake!', seemed to owe as much to Swedish Romantic poetry as it did to German Nazi propaganda:

\footnotetext{
${ }^{67}$ First and last stanza from 'Vaknen!', in: Rydberg, Dikter, pp. 56-57.

${ }^{68}$ 'Meddelande från Plg', DSN, no 32, 21 December 1933, p. 2.
} 
Goths fight the struggle for freedom

South from Eystrasalt,

Let the scourge of truth sting,

Over the figure of lies.

Brothers, friends, sons of Svithiod,

Gather together, a united tribe!

$[\ldots]$

Truth, folkgemenskap, harmony,

Freedom, work and bread,

Those are goals we want to advance,

Put them up against starvation and want.

Listen Swede! From the cairns,

The father's spirits' voice:

'SWEDEN AWAKE! Hear our call!'

Let the answer fill each Swedish breast ${ }^{69}$

Around 1935 a shift occurred, towards a more explicitly Gothicist interpretation of party ideology. In part this may well have had something to do with the self-conscious development of a more overtly national fascism, to 'naturalise fascism', as Swedish fascists were embarrassed by

\footnotetext{
${ }^{69}$ En virde, 'Sverige Vakna!', DSN, no 3, 18 January 1934, p. 6.
} 
Nazi Germany's declining international reputation. ${ }^{70}$ While preoccupations with biological race in Nordicism by no means stemmed from Germany, it had become heavily associated with German Nazism by the 193 os.

Where earlier material in DSN on the topic of Nordic heritage had predominantly dealt with biological race, emphasis moved to culture. This was evident in some small ways like the pagan elements of the annual winter march that came to be arranged on New Year's, and its reference to the revival of ancestral customs to stay true to the National Socialist path, and not be misled by the 'decadence of a life of pleasure or the irritations of daily life'. ${ }^{71} 1936$ saw a two-part editorial in DSN which promoted the Viking era as a 'Nordic Golden Age' [nordisk storhetstid], hoping to rehabilitate it as a time of Nordic military, economic, cultural, and moral superiority, in struggle with a decadent Roman-Christian West. $^{72}$ The decline of the Nordic era was blamed primarily on the introduction of Christianity, but a revival of Nordic strength in the early modern period was explained principally with reference to Gothicism:

The spiritual power, which during this time galvanised our people, was at least partially derived from the old Nordic memories. The Gothicism of the 16oos is the Nordic background to this power development. The Nordic research into the ancient past [nordiska fornforskningen] got its first period of prosperity in our country. And the Nordic world view received a mighty and special expression in Rudbeckianism. ${ }^{73}$

\footnotetext{
${ }^{70}$ Kunkeler, 'The Evolution of Swedish Fascism', pp. 383-87.

${ }^{71}$ Argus, 'Där vi kämpa: Midwintervaka i Ånga', DSN, no 2, 8 January 1936, p. 5 .

${ }^{72}$ H.J., 'Vikingatiden - en nordisk storhetstid: Nordlandets kamp mot västerlandet', DSN, no 45, 14 June 1936, p. 4.

${ }^{73}$ H.J., 'Vikingatiden - en nordisk storhetstid: Nordlandets kamp mot västerlandet', DSN, no 46, 17 June 1936, p. 4.
} 
The Nineteenth Century had promised a Nordic revival, but was ultimately hamstrung from the beginning due to the untraditional politics of a foreign monarch, Karl Johan Bernadotte. ${ }^{74}$

In the same DSN issue it was announced that a new Party Leader flag was to be introduced, using a Tiwaz rune as its symbol. As the article explained, the rune was symbolic of the god Tyr, identified as a son of Odin. Tyr, DSN explained, was the god of soldiers who sacrificed his right hand to bind the wolf Fenrir. ${ }^{75}$ (The explanation follows the story as written by Rydberg in Fädernas Gudasaga. $)^{76}$ In 1937 the annual party congress was designated a revival of an Old Nordic institution, the ting, where the Viking chieftain was counselled by his confidants. ${ }^{77}$ In February 1939, the party arranged a tour of the rune stones of Uppland (Uppsala, Stockholm), not the first one done by the SSS Stockholm group, as a way of experiencing Swedish history first hand, and maintaining the heritage of the ancestors..$^{78}$

From 1935 onwards the NSAP's youth organisation, Nordisk Ungdom (NU, Nordic Youth), started to take a more prominent place within the movement. While youth had always been idealised in the NSAP and its predecessors, it was increasingly emphasised as a definitive characteristic of the party, not least as the Party Leadership realised the bulk of its support came from people under the age of twenty-three. ${ }^{79}$ Lindholm increasingly highlighted NU's task to educate the young, physically and culturally. As membership grew, and was put under the leadership of the young radical Arne Clementsson, the NU started to be characterised as 'the [embodied] struggle for tradition and revolution', a group yet untainted by modern society,

\footnotetext{
${ }^{74}$ Ibid.

${ }^{75}$ 'Ledarens stabsflagga', $D S N$, no 45, 14 June 1936, p. 5 .

${ }^{76}$ Rydberg, Fädernas Gudasaga, pp. 232-36.

77 'Ledardagen: På gammal nordmannased rådslog vår Ledare med sina främstra förtroendemän om frihetsrörelsens kommande uppgifter', DSN, no 38, 19 May 1937, p. 4.

${ }^{78}$ T. L-n, 'En SSS-färd till Upplands runstensrikaste bygd: I Jarlabankes gamla domäner', $D S F$, no 14, 22 February 1939, p. 5 .

${ }^{79}$ Police report, 'Översikt över nationalsocialismen i Sverige', 5 October 1935, p. 19, SÄPO archive, Arninge, file $2 \mathrm{~B}: 4$ (Teser, programm, upprop m.m.).
} 
inheritors of ancestral tradition. ${ }^{80}$ Since spring 1934 emphasis was put on sports and gymnastics [friluftsliv och idrott], particularly in the Swedish landscape, which would teach the boys and girls 'love for the Nordic person, the will to act and think Nordic' - a goal in tune with the gymnasticnationalist educational agenda of the previous century. ${ }^{81} \mathrm{NU}$ groups regularly went to summer camps and on winter marches. 1938 Lindholm explicitly stated these aimed at 'Nordic-cultural education' [nordisk-kulturell fostran], familiarising the young with traditional songs, games, and stories. ${ }^{82}$ Lindholm remembered this as a key point of NU in his 1980-81 interview: 'Nordic Youth engaged mostly in cultural politics [kulturpolitik]', practicing dance and poetic declamations. ${ }^{83}$

Lindholm and the party's focus on youth, tradition, gymnastics, and Nordic culture does not stand out amongst the fascist movements of Europe in the 1930s, but it had a peculiarly Scandinavian, and indeed Swedish background, which tied all of these themes together as elements of a holistic Gothicism. It is not immediately clear why this Gothicist tendency took some time to manifest in the party: Lindholm had immersed himself in the tradition for years before he founded the NSAP in 1933, but it was only towards the end of 1934 it became evident in his writing for DSN. Even his own poetry, which littered DSN's pages from the outset, followed this development. Early poems like 'Solryttarsång’ [Sun rider song], 'Sången om Goliat' [Song of Goliath], and 'Svensk Morgon' [Swedish Dawn], contain conventionally nationalist elements, as well as anti-Semitic and Nazi race themes, but little that alludes to the Leader's literary

\footnotetext{
${ }^{80}$ Nilef, 'Sveriges ungdom för ungdomens Svarige: Nordisk Ungdom får framåt!', $D S N$, no 47, 19 June 1935, p. 6.

${ }^{81}$ 'Nordisk Ungdoms mål och medel', $D S N$, no 10, 8 March 1934, p. 5.

${ }^{82}$ Sven-Olov Lindholm, 'Nationalsocialistisk midsommar i Södermanland: Nordisk Ungdom kallar till samling!', $D S N$, no 36, 18 May 1938, pp. 1, 4 .

${ }^{83}$ Lindholm interview, 00258:B, c. 28 mins.
} 
education. ${ }^{84}$ Even his 'Vikingasång' is as much about Jewish oppression of an Aryan race as the Nordic-Gothic tradition. ${ }^{85}$

The delayed shift to more overt Gothicism can partly be attributed to the aforementioned alienation from the Nazi regime, which culminated in the November 1938 makeover, possibly prompting Lindholm to find ideological inspiration elsewhere. During the war, as NCO in the Swedish army, Lindholm was especially keen to deny associations with German Nazism. 'The party fights ... for a social order which, in our opinion, is better and more effective that the current one. This order to which we aspire is not "foreign", as some want to make out, but is rather based on purely Swedish traditions and Nordic standards of justice [rättsuppfattning]. ${ }^{86}$ But there may be another reason, which is his exposure to a writer who arguably became his unexpected main and fundamental influence in the second half of the 193os: Are Waerland.

\section{IV}

Are Waerland (1876-1955) was a Finno-Swedish popular philosopher and dietician, and inventor of the Waerland diet, still followed by some today. Throughout the interwar period he wrote on a variety of topics, including the Russian Revolution, idealist and materialist philosophy, Swedish national character, the virtues of the human colon, the dangers of white sugar, and his hobby horse, $k r u s k a$ porridge.$^{87} \mathrm{He}$ was engaged in a lifelong project to research and prove that all disease

\footnotetext{
${ }^{84}$ 'Solryttarsång', DSN, no 4, 1 March 1933, p. 4; 'Sången om Goliat', DSN, no 20, 21 August 1933, p. 6; 'Svensk Morgon', $D S N$, no 9, 1 March 1934, p. 6; all poems published under the name Sven Olov.

${ }^{85}$ Sven-Olov, 'Vikingasång', DSN, no 24, 1 October 1933, p. 7 .

${ }^{86}$ Letter, Lindholm to Chief of the Army, Stockholm, 3 July 1942, Marieberg, Lindholm's archive, vol. 5 .

${ }^{87}$ Kruska is made by putting seeded raisins in water, and leaving them overnight for a period of twelve hours. One hour before serving, the water is boiled, and a measure of oat meal added while stirring with a long wooden spoon. After two to three minutes, special wheat germs are added to the mixture until it has a gruel-like consistency. The whole thing is then left for half an hour in a warm, sealed box. It is ideally served with a helping of milk. Are Waerland, Kruskan som kraft- och hälsoföda (Göteborg: Örnförlaget, 1939).
} 
was the result of internal physiological degeneration, and that with the correct diet and lifestyle, all diseases - not least cancer - could be prevented. Consequently, all medicine ought to be strictly preventative. His ideas, expressed in colourful metaphors, and framed in a discourse of the purity of nature against the corruption of civilisation, also had a racial bent to them. The degenerate English were described as the most corrupted race due to their supposedly advanced civilisation. Istead, Waerland's hope was the Nordic nations, now under attack but who could still be saved from the diseases of modernity. ${ }^{88}$ His ethos is summed up by his 1938 book, Död åt det vita sockret - Liv åt de vita folken (Death to white sugar - Life for the white peoples). ${ }^{89}$ Proudly displaying his own health and fitness at the age of sixty as a proof of the efficacy of his methods, Waerland toured Scandinavia and Germany to lecture on public health.

The evidence for Waerland's influence on Lindholm is very clear. His diary entry for 1 November 1936 simply reads “became "wærlandist” (part of Are Wærland's nutritional experiment) ate only kruska and raw food $[$ råkost $] .^{90}$ The subsequent entries show that he also discussed Waerland's ideas with his family over Christmas the following month. Earlier entries that year suggested he was already trying the diet, and mentioned eating mostly raw vegetables. In April 1937, an article by Lindholm appeared in DSN, reporting on a Waerland lecture he had attended in Gothenburg. Lindholm enthusiastically recounted Waerland's health advice, particularly the need to avoid 'decomposing foods' and food generating uric acid - white sugar, baked goods, alcohol, and so forth, in favour of rye flour and uncooked root vegetables. The lifestyle also required more exercise, and less warm clothing. One needed 'galvanising physical exercise out in the open, fresh air day and night - we should expose the body to both exertions and temperature shifts and cold

\footnotetext{
${ }^{88}$ Are Waerland, In the Cauldron of Disease (London: Nutt, 1934), p. 374.

${ }^{89}$ Are Waerland, Död åt det vita sockret - Liv àt de vita folken (Stockholm: Reformförlaget, 1938).

${ }^{90}$ Lindholm diary, 1 November 1936.
} 
winds, simpler and more Spartan living conditions'. Lindholm ended the article by recommending party members to heed Waerland's advice..$^{91}$

It is in kruska that the impact of Waerlandism on Lindholm was most obvious. A week after converting to 'Waerlandism', Lindholm taught the NSAP Party Leadership how to cook the porridge. He spent the New Year's morning of 1937 morning marching in the woods with party members, and cooked kruska for the fifty men present. By spring he was teaching rank-and-file members how to cook it. ${ }^{92}$ One can only imagine how the cadres felt about their Leader's porridge cooking classes. According to DSN, the propaganda summer tour of 1937 had the customary NSAP propaganda team divided into two camps in terms of food, between a minority of 'corpse-eaters' [likätarna] and a majority of 'onion-eaters' [lökätarna], 'living of lacto-vegetarian raw food according to the Waerland-method'. In the morning everyone partook of large portions of kruska, the excellent qualities of which everyone could agree on. ${ }^{93}$ For the summer of 1938 , DSN requested members to donate foodstuffs to the propaganda team, including 'kruska ingredients', especially seeded raisins, carrots, and 'simpler vegetables' ${ }^{94}$ Lindholm was already renowned in the party for his ascetic habits, but the diet might have taken things a little too far for some members. ${ }^{95} \mathrm{~A}$ report by a secret police informant in 1937 tells that: '[s]ome members are also unhappy because Lindholm has now (like Hitler) gone in for the raw food principle. Many members do of course want to have a [glass of] schnapps when the opportunity arises, and feel that they can be equally good comrades for that ${ }^{\prime 6}{ }^{9}$ While the comparison to Hitler's diet was misleading, the report unwittingly indicated that Lindholm's advocacy of Waerland was raising some eyebrows. It may

\footnotetext{
${ }^{91}$ S. L-m, 'Are Waerland talar för sundare livsstil: Entusiastiskt hyllad vid möte i Göteborg', DSN, no 26, 7 April 1937 , p. 4.

${ }^{92}$ Lindholm diary, 9-13 November 1936, 1 January and 20 March 1937.

93 'Under Tyrsflaggan: Med propagandalaget i fält', $D S N$, no 61, 11 August 1937, p. 6.

94 'Ut i fält! Skänk livsmedel åt våra aktiva frontmän', $D S N$, no 43, 15 June 1938, p. 5 .

${ }^{95}$ See for instance: Note from Lindholm, 1935 (Spring), Marieberg, NSAP/SSS Archive, vol. 1.

${ }^{96}$ Police memorandum, S. Fransson regarding splits in the NSAP, 27 February 1937, p. 1, Arninge, XII 64: 1.
} 
well be the case that Waerland's influence on Lindholm impacted negatively on his ability to lead the party, and had some role to play in the party split that followed the 'New Direction' of NSAP/SSS in November 1938.

Waerland's influence on Lindholm went beyond diet and exercise however, and must have predated the latter's adoption of the diet in 1936. Apart from the distinctly racialist bent to Waerland's lifestyle advice, he had also written on a range of other topics before the 192os, including racial science.

Känn dig själv: En studie av den svenska folkkaraktären (1917, Know Yourself: A study of the Swedish racial character) is a case in point. In this work Waerland explained the nature of the Swedes with reference to their Germanic racial characteristics, such as the supposed Germanic state-building tendency, and the capacity for organisation and rule [härskning]. Citing Rolf Nordenstreng, (who had incidentally also written a book on the poetry of Gripenberg), Waerland described Sweden as 'the most racially pure North-European country in existence'. ${ }^{97}$ But, he argued, in spite of the Swedes' Germanic tendency towards empire-building, as seen in the historic dominion over Russia, they lack endurance as a race, with no eye for the practical and feasible, as demonstrated by adventurous but risky ventures such as the Viking raids of the Middle Ages, or the wars of Charles XII. ${ }^{98}$ Building on familiar fin de siècle themes of national decline, Waerland argued that the Swedish race is too prone to look outwards, emotionally stunted, and lacks a strong sense of spirituality, at the expense of the people's national instincts. ${ }^{99}$ It is here that a more far-reaching influence on Lindholm becomes evident. The Swedish racial character was described with reference to Tegnér's depiction of Fritjof in Fritjofs Saga, while Swedish national decline, and

\footnotetext{
${ }^{97}$ Are Waerland, Känn dig själv: En studie av den svenska folkkaraktären (Helsingborg: Logik, 2017), p. 23. Note that Waerland's works are now reprinted by far-right publishers.

${ }^{98}$ Waerland, Känn dig själv, pp. 26-46.

${ }^{99}$ Waerland, Känn dig själv, pp. 93-105.
} 
the lack of patriotism, was illustrated with none other than Heidenstam. "There is not a backwater in Europe", wrote Heidenstam in 1896, "where patriotism [fosterlandskärleken] lies as dead behind hollow words as with us..." ${ }^{\text {10o }}$ Real Swedish spirituality and patriotism could, according to Waerland, be found in the masterpieces of Swedish poetry, reaching great heights through its inspiration from the Swedish natural landscape. 'What force and what calm in the poetry of a Runeberg, what majestic stature in that of a Tegnér and a Heidenstam, what titanic defiance in a Strindberg, and what great heights in the poetry of a Rydberg! ${ }^{\text {101 }}$

There is nothing to prove definitively that Lindholm read Känn dig själv, but it demonstrates that there was a strong resonance between Lindholm's educational background and literary interests, and the arguments and rhetoric of Waerland, which implies that the latter may well have influenced the fascist leader in what he read, and how he interpreted it. As Lindholm came to codify the Swedish influences on his fascism from the 193os onwards, it was more than a coincidence that the recurring poets in his thoughts were almost identical to those found in Waerland's works.

At the May 1935 NSAP congress, held during the peak of the party's growth, Lindholm closed the proceedings with a lengthy speech for a crowd of six thousand people on the Östermalm square in Stockholm. The speech was filled with the usual fascist hobby horses, with attacks on capitalists, Marxists, Jews, the Social Democrats, and democracy. Starting with a portrayal of the rise of the NSAP in the past two years, in the context of a supposedly faltering democracy, Lindholm ended the speech with an appeal to sacrifice, and the power of National Socialism to grasp and alter the course of Swedish history. In the rhetorical climax of the convention, Lindholm shouted:

\footnotetext{
${ }^{100}$ Waerland, Känn dig själv, p. 103.

${ }^{101}$ Waerland, Känn dig själv, p. 129.
} 
Yes - we wish to continue the history of Sweden, says the answer which resounds from the northern land's fells to Öresund - from the western- to the eastern land! Yes - we wish to confess to the people's will which flows in our own blood! Here we wish to found a free motherland for the workers, and here fight for that culture which can speak to Nordic hearts, to the people's own soul! ${ }^{102}$

In an idiosyncratic move, he proceeded to recite two stanzas from the poem 'Grubblaren' ('The Brooder') by Viktor Rydberg. ${ }^{103}$

There are woven, circling in space, stars and thoughts, circling in human brains, there is woven generation, there is woven death, and the shape of things and the destiny of nations.

There patterns are made, shifting and bright, like nerve threads, quivering in desire and pain, but the pattern's theme is eternally set, an unrelenting, ceaseless struggle for life. ${ }^{104}$

The poem, as Lindholm explained to his audience, compares human life to a weave spun throughout time and history, in which it is human action that forms the pattern. The

\footnotetext{
${ }^{102}$ Sven Olov Lindholm, “Svensk frihet är vår lösen”: Lindholms tal på Östermalmstorg i Stockholm', DSN, no 48, 23 June 1935, p. 4.

${ }^{103}$ The figure of the brooder was probably a reference to Odin, see: Rydberg, Fädernas Gudasaga, p. 39.

${ }^{104}{ }^{D S N}$, ibid. ${ }^{104}$
} 
interpretation linked the poem to typical fascist themes, of nation, action, sacrifice, and struggle. But the reading of the poem was not Lindholm's own. In Are Waerland's 1924 popular philosophical tract, Idealism och Materialism, Waerland used Rydberg's ‘Grubblaren’ by way of illustration, in an argument attacking materialist philosophy. The two stanzas Lindholm recited were also among the seven Waerland quoted in his book (out of the fifty-two in the complete version) $\cdot{ }^{105}$ Comparing Lindholm's speech and Waerland's text, it is evident that Lindholm was in fact citing Waerland almost verbatim in his explanation of the poem at the party congress.

There can be no reason to doubt that Lindholm read Waerland's older philosophical tracts, and while his conversion to 'Waerlandism' was only in late 1936, his first readings can have been no later than the beginning of 1935 on the basis of this incident, but Waerland's influence may well have started earlier than that.

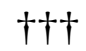

As this article has shown, there is clear evidence for the literary influences on the leader of Sweden's largest fascist movement in the interwar period, the NSAP/SSS. Reading the material from Lindholm's private archive, the party archive, and DSN, we get a clear perspective on the rich literary background of Lindholm's politics from his youth through to the end of his political career. It has not been my intention to deny the relevance of foreign influences on Swedish fascism. Without the momentum for a new Rightist politics generated by the 1922 March on Rome, or the subsequent impetus generated by the success of Hitler's NSDAP, the fascist or National

\footnotetext{
${ }^{105}$ Are Waerland, Idealism och Materialism (Uppsala: J.A. Lindblads Förlag, 1924), pp. 29-30.
} 
Socialist movements of Sweden would have been unimaginable. ${ }^{106}$ Likewise the Swedish connections with the NSDAP in Germany since the 1920 are obvious, and the NSAP adopted much of the German party's organisation and style wholesale - there is no need to deny some degree of mimesis, even if that process was selective and complicated. Nor have I meant to imply that the cited elements of Swedish literary culture, specifically Gothicism, were in any way 'protofascist', (whatever that means), as if the evolution of political phenomena can be traced through such a linear, teleological genealogy. But it has served to explain why fascist ideas in Europe might find fertile soil anywhere at all, and why it did among specific social groups, such as Swedish school youth, and the military - people like Lindholm himself. In this sense it has been a personal case study of the adoption and formulation of fascist ideas. Secondly it elucidates the interaction between new Rightist ideas after WW1, and older nationalist ideas already in circulation, both conservative and liberal.

The Romantic literary education of Lindholm is not unexpected, and matches what many scholars of fascism have found, though usually formulated in terms of an anti-rational reaction against the Enlightenment, and an intersection with fin de siècle cultural pessimism. ${ }^{107}$ In the Swedish case this has not been explored before however, and this been rarely been investigated through specific authors and texts, which the subject in question had demonstrably read. In this instance Lindholm has provided a unique opportunity. The aspect of Gothicism has highlighted an unusual side to Swedish Romanticism, and shown a cultural influence on fascism in Scandinavia that goes back even further, as seen in Rudbeck's Atlantis. The nineteenth-century project of a revived Gothic-Viking masculinity interacted intriguingly with Nazi racial Nordicism, in a way it

\footnotetext{
${ }^{106}$ Aristotle Kallis, 'Fascism and the Right in Interwar Europe: Interaction, Entanglement, Hybridity', in The Oxford Handbook of European History, 1914-1945, ed. by Nicholas Doumanis (Oxford: Oxford University Press, 2016), pp. 306-10. ${ }^{107}$ E.g.: Mark Neocleous, Fascism (Buckingham: Open University Press, 1997), pp. 1-6.
} 
did not outside of Scandinavia, the actual birthplace of Nordicism. ${ }^{108}$ This has situated Swedish fascism within a wider nationalist cultural network, which had been disseminated through the educational system.

Are Waerland was unexpectedly perhaps the most influential of the Swedish writers for Lindholm. The personal impact on Lindholm is obvious, but the timing of his discovery by the leader, though a little uncertain, can provide us with the greatest insight. Putting the spotlight on the proposed 'Gothicist shift' in the NSAP around 1935, the cited Swedish literature in Waerland's writings imply he may have helped Lindholm codify the Swedish nature of NSAP fascism. The early 1930 s saw a kind of Swedish Gothicist-Nazi intellectual mixture, combining ideas in a fairly predictable way as German race ideology met indigenous traditions. But it is with the Gothicist shift, and Lindholm's discovery of Waerland, that we see Lindholm explicitly bringing out the intellectual connection between Swedish literary ideas and fascism. Doubtless the impetus for this shift towards naturalising fascism lay at least partly in political necessity, but the connection between Lindholm, Waerland, and the Swedish literary classics sheds light on how the organisation moved from fascist adoption and hybridity, towards the codification of a Swedish fascism.

\footnotetext{
${ }^{108}$ Bernt Hagtvet, 'On the Fringe: Swedish Fascism 1920-1945', in Who Were the Fascists?, ed. by Stein U. Larsen (Oslo: Universitetsförlaget, 1980), p. 586.
} 